\title{
最近のCAD/CAM・システム化技術 ${ }^{*}$
}

勘 定 義 弘 $^{* *}$

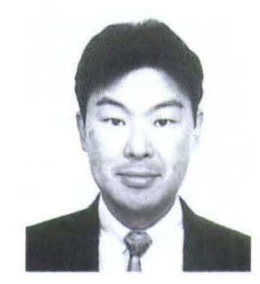

Latest CAD/CAM - Systemization Technoology in Welding*

by KANJO Yoshihiro **

キーワード CAD/CAM, シュミレーション, マルチロボット, CAPM

\section{1.はじめに}

近年のコンピュータ技術の著しい進歩にともない, 従 来, 困難とされてきた多品種少量生産の業種においても, 溶接ロボットの適用事例が増加している. 近年の特徴と して, $\mathrm{CAD} / \mathrm{CAM}$ と組み合わされたマルチロボットシス テムとして高効率化が四られている点に注目することが できる.

その背景として, 設計ツールである $\mathrm{CAD}$ が 2 次元から 3 次元へ進化するとともにロボットシミュレーション技 術が発達し，パソコン内の仮想空間にて干涉チェックな どのシミュレーションが容易に行えるようになったこと がある。

本稿では，いつくかの CAD/CAM 開発事例とシステム 最適化技術の概要を紹介する。さらに，ロボットをより 効率的に活用するためのシステム化技術として, シミュ レーション技術および, 日程計画システムを簡単に紹介 する.

\section{CAD/CAM 技術}

生産ラインの停止など, 現場でのロボットのティーチ ング作業に起因する生産性の低下を解消する手段として 開発されたオフラインティーチングシステムは, CAD と リンクさせることで $\mathrm{CAD} / \mathrm{CAM}$ システムとして発展, 進 化してきた，以下，いくつかのシステムを紹介する.

\section{1 建築鉄骨の CAM}

建築鉄骨の業種では, 柱の大組立工程に溶接ロボット が利用されている. 対象が比較的単純な柱構造をしてい ることから，図 1 に示すようなコンピュー夕面面より,

*原稿受付 平成15年 1 月8日

**正員 日本鋼管侏 Member, NKK CORPORATION
柱寸法, 板厚などの部材形状情報をオペレータが入力す ることで, ティーチングデータと同等のロボット動作プ ログラムが自動生成される CAM システムが開発されて いる. 本システムの特徴は $\mathrm{CAD}$ 情報を必要としない点で あり, 本システムを利用して図 2 に示すような鉄骨柱大 組立ロボット溶接システムが開発されている.

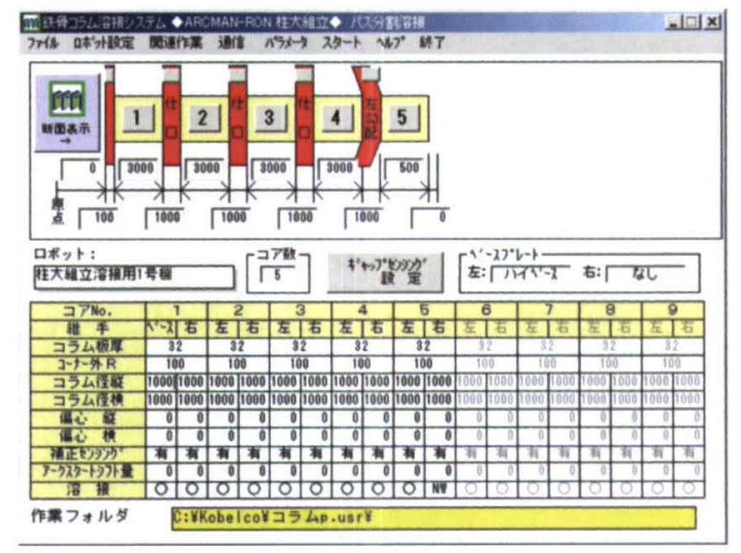

図 1 建築鉄骨用CAMシステム

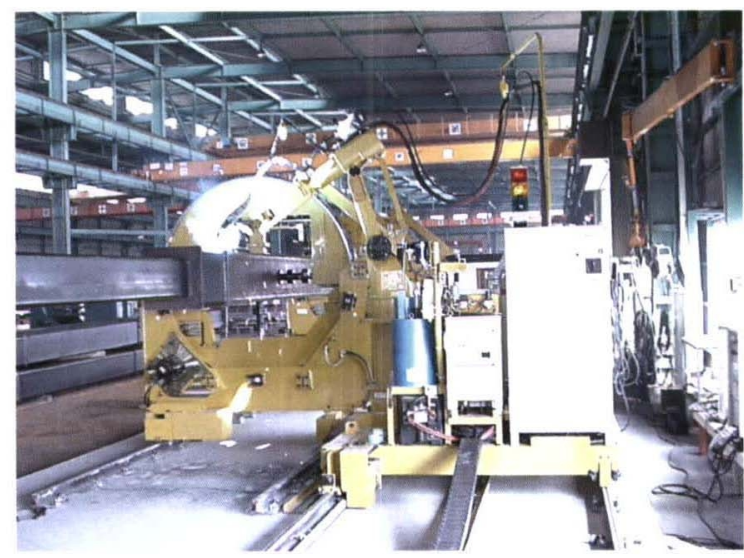

図2 建築鉄骨用溶接口ボットシステム 


\section{2 機械・鋼構造物の CAD/CAM}

工作機械や建設機械に類する業種においては CAD を利 用した設計が普及しており，CAD でモデリングした対象 ワークの 3 次元形状情報が構造解析（CAE）に利用され たり，NC 工作機械用情報として利用"されたりしている. これらの業種では, 多品種少量とはい元類似ワークが繰 返し組立られることから，ワーク種類ごとにロボット溶 接に必要な溶接属性情報をあらかじめ定義しておき, $\mathrm{CAD}$ の 3 次元形状情報と合わせることでマルチロボット の動作プログラムを自動生成させる方式の $\mathrm{CAD} / \mathrm{CAM}$ シ ステムが開発2されている。

図 3 は, 本方式の例として, 地下トンネルに利用され る鋼製セグメントのマルチロボット溶接システム ${ }^{3)}$ に利用 されている $\mathrm{CAD} / \mathrm{CAM}$ システム構成を示したものであ る. CAD には市販の 3 次元 $\mathrm{CAD}$ が利用されているが, 溶接線を識別させるための溶接線定義機能が追加されて おり，ワーク形状情報と溶接線情報とが各々 CAM 側に 渡される。

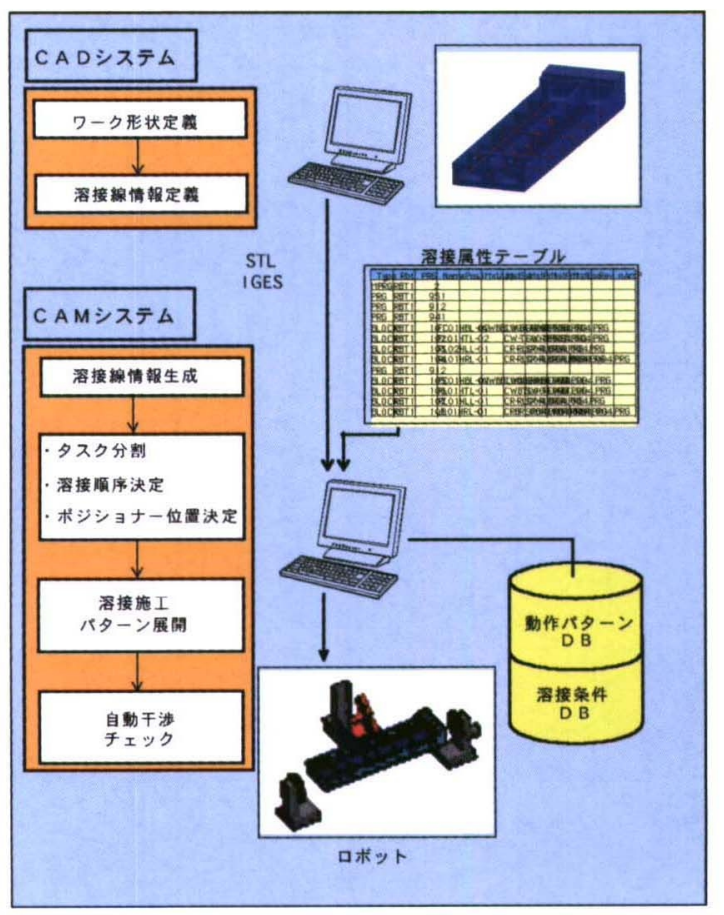

図3 機械·鋼構造物用 CAD/CAM システム構成

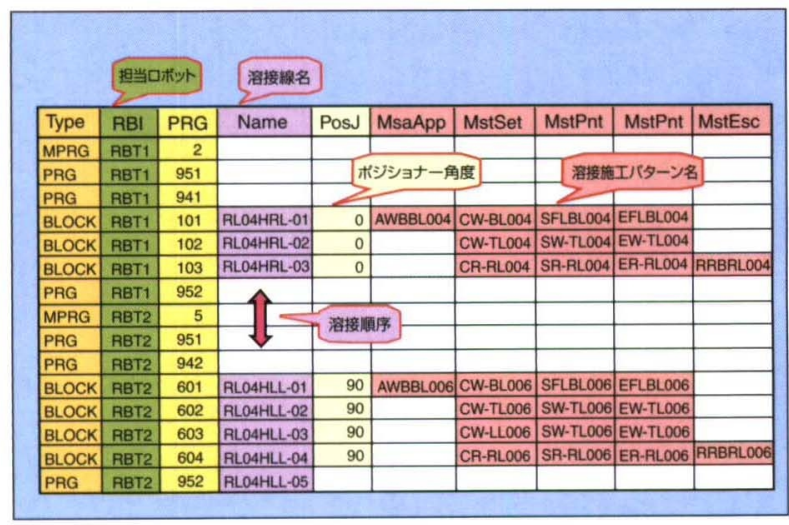

図4 溶接属性情報
CAM では，別途読み込んだ溶接属性情報と各溶接線の 位置情報とを照合する溶接線情報生成処理，ロボットの 作業分担を行うタスク分割処理，ポジショナ角度ごとの 溶接順序決定処理，動作パターンデータベースと溶接条 件データベースを利用した溶接施工パターン展開処理が 順次実施され，ロボット動作プログラムが自動生成され る. 自動処理に不可欠な溶接属性情報には, 図 4 に示す ように溶接線ごとに，担当ロボット，溶接線名，溶接順 序，ポジショナ角度と，アプローチから溶接，リトラク トに至る一連のロボット動作を定義する溶接施工パター ン名がテキスト形式で定義されている。このように溶接 属性情報を定義しておくことで CAM システム処理を簡 易化している.

生成されたロボット動作プログラムは, 図 5 に示すよ うにロボットシミュレータにかけられ，ロボットがワー クに干渉しないかが自動的にチェックされる。対象ワー クの 3 次元形状情報はこのシミュレーションに利用され る。干涉が発生した場合にのみオペレータがロボット位 置・姿勢を修正する．以上の処理の後，ロボット動作プ ログラムは, 各ロボットへと送信される，近年，LAN 対 応のロボット制御装置が開発されており，上位の CAD か ら末端のロボットまで同一のネットワークで接続が可能 となっている.

\section{3 橋梁・造船の $\mathrm{CAD} / \mathrm{CAM}$}

橋梁業界では, 鈑桁, 箱析のパネル構造部材の組立に, また，造船業界では，トランスパネルの組立にマルチロ ボット溶接システムが適用されている．これらの業界で は，工作情報を作成する目的の専用 $\mathrm{CAD}$ が開発利用され ており，CAD からの出力情報は，溶接線の位置情報の他 に，溶接対象となる部材の高さ，板厚，部材端形状，溶 接設計情報としての隅肉脚長などが，特定の書式で出力 される。

本 CAM システムの特徴は, 図 4 にて説明した溶接属 性情報を必要とせず，すべて自動処理されている点であ る.図 6 に示した造船用 $\mathrm{CAD} / \mathrm{CAM}$ システム4では, ロ ボットの作業領域に対応した自動タスク分割処理，所定 のアルゴリズムによる自動溶接順序決定処理, 溶接施工 パターンの自動決定処理, 自動干渉回避処理が機能とし て具備されている。本 CAM システムは，ロボット動作 データ生成システム，ロボットプログラム生成システム，

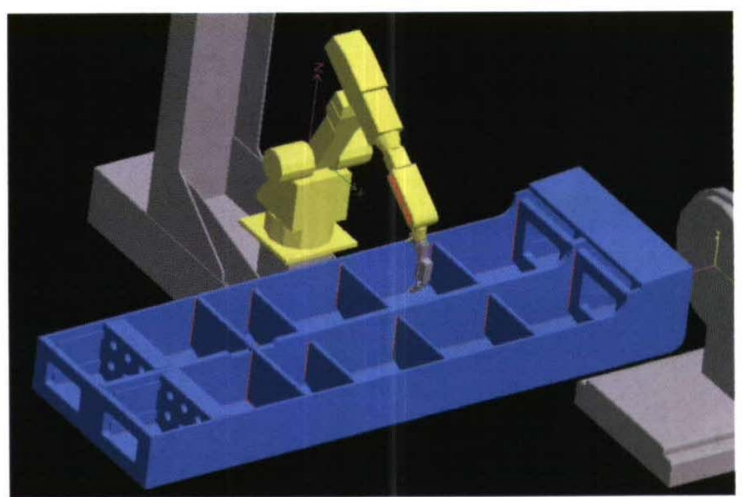

図5 ロボットシュミレーション 


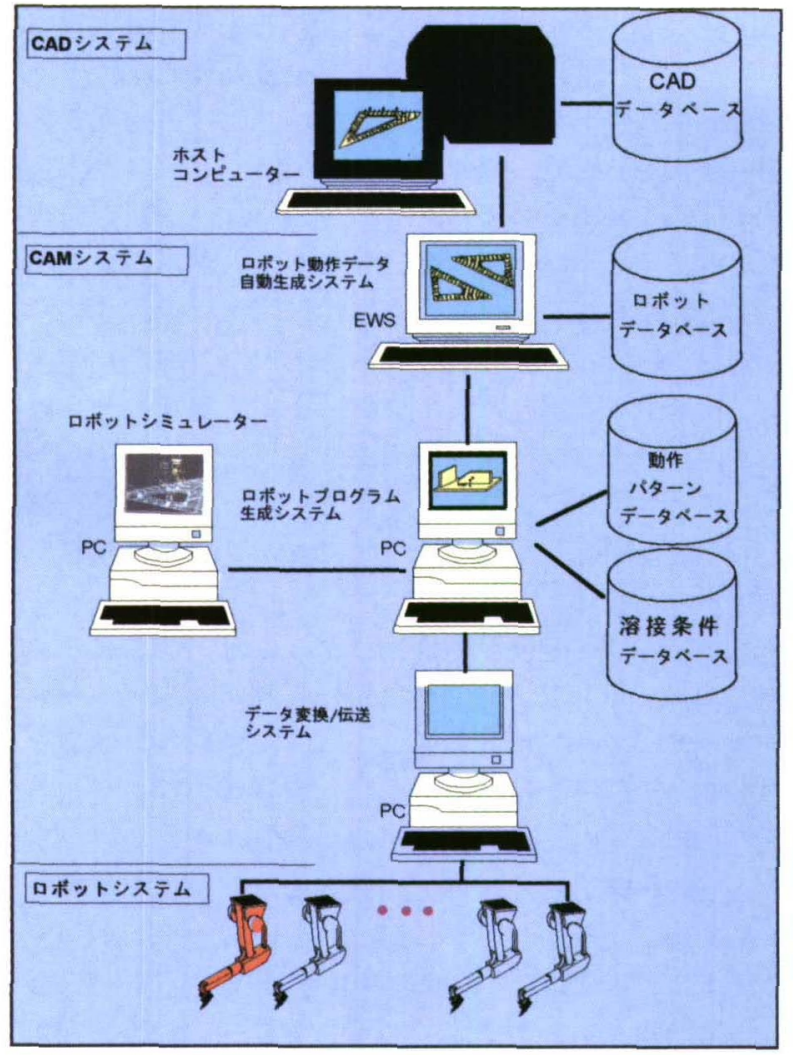

図6 造船用CAD/CAMシステム構成

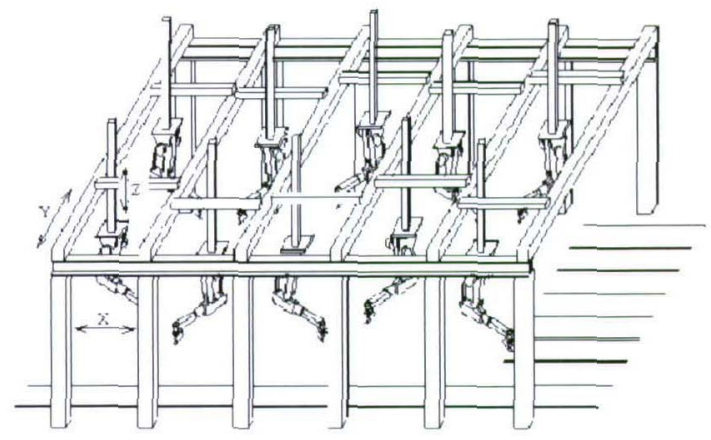

図7 造船マルチロボットシステム構成

ロボットシミュレータ，ロボットデータ伝送システムか ら構成される。

\section{$2.4 \mathrm{CAD} / \mathrm{CAM}$ 最適化技術}

図 7 は造船に用いられているマルチロボット溶接シス テム構成を示すが，このように多数台のロボットを高密 度に配置したシステムレイアウトでは，ロボット動作時 の相互干渉が問題となってくる。この課題に対して, 近 年，遺伝的アルゴリズム（GA）を用いて溶接順序の入れ 替えを行い，ロボット相互の干涉を回避する経路最適化 の研究5がなされている．遺伝的アルゴリズムとは，自然 界において生物が遺伝子の交义や突然変異そして淘汰に より進化していく過程を模擬した最適化手法である。

図 8 に今回の遺伝的アルゴリズムの処理フローを示す.

1) 溶接経路の遺伝子表現 GAにおいて一般的な 0 か 1 の 2 值表現ではなく, 図 9 に示すような R 1 か ら R10 までの10台のロボットの担当する溶接線番 号を一列に並べて溶接経路の遺伝子表現としてい る.

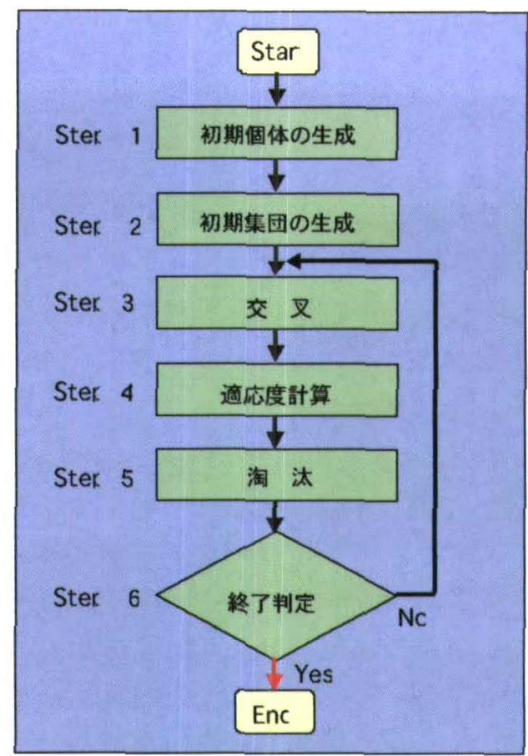

図8 遺伝的アルゴリズムの処理フロー

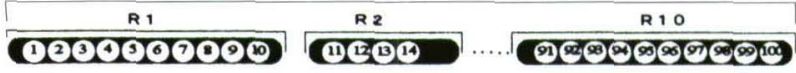

戝9＼cjkstart溶接経路の遺伝子表現

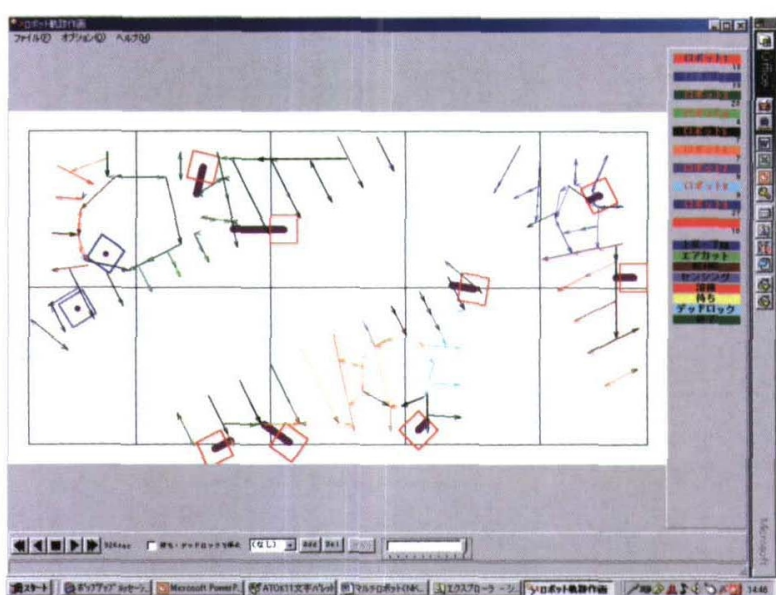

図10 マルチロボットシミュレータ

2) 交叉の方法 特定のロボットをひとつ選択し，そ の中の特定区間の溶接線番号列を同一ロボット内 の別の位置に移動させる.

3) 適応度の計算方法 四10に示すような専用のロボ ットシミュレータにより，全ロボットの動作をシ ミュレーションすることで, 全体の作業時間を求 める.

4) 淘汰の方法 作業時間の短い個体が優先的に選択 し，次世代に残されるようなランキング戦略を用 いている.

\section{3. シミュレーション技術}

3.1 ロボットシミュレーション

すでに述べたようにロボットシミュレーション技術は， 


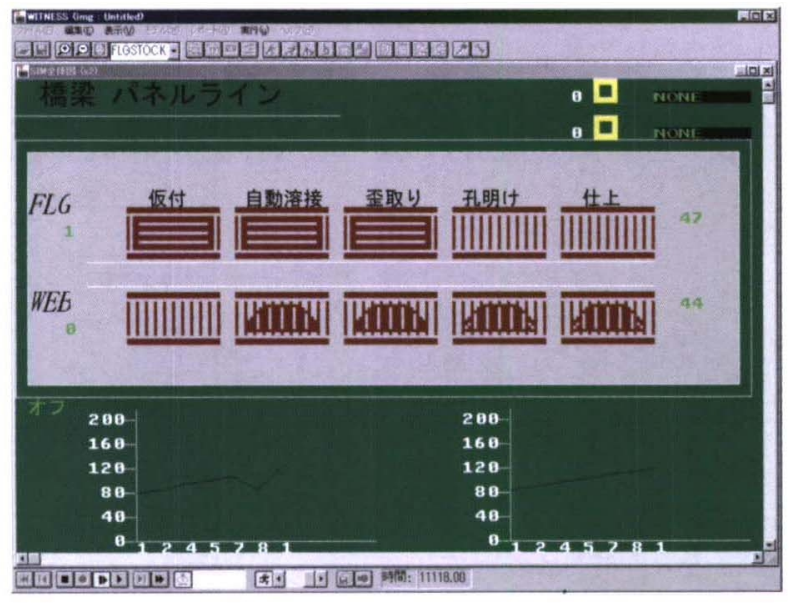

図11 物流シミュレーション

$\mathrm{CAD} / \mathrm{CAM}$ システムには不可欠な技術であり, 対象ワー クとロボットとの干渉チェックに用いられている。その 他, 新規設備導入時や新製品の開発時の事前ロボット施 工検討にも用いられており，例えば，ロボットとポジシ ヨナの配置関係を調整することで，対象となる溶接線に 無理なくロボットがアプローチできるかを CRT 上で確認 できる。

\section{2 物流シミュレーション}

溶接を中心とする組立工程においてはライン化が図ら れて抢り，設備の効率的運用が課題となっている. 物流 シミュレータは, 設備の稼働状況を仮想空間上でシミュ レーションできるッールであり, ライン設備の稼働率, 工程間ストック，ライン処理能力などの時間的推移を定 量的に把握できるとともに，四11に示すようにCRT 画面 上で可視的な判断が可能であることが特徵である. 例え ば，ライン上のどの工程がボトルネックになっているの かということを簡単に確認することができる。このよう な物流シミュレーションは, 工場全体という大きな規模( でも実施されて扔り，生産技術者が机上で検討していた レベルをしのぐものであり，まさに技術革新である.

\section{4. 生産管理システム}

生産管理システム (CAPM: Computer Aided Production Management）開発に関しては, 重工製造業においても積 極的に取り組まれてきている. 中核となる生産計画につ いては, 図12に示すように階層的なシステム化がなされ ていることが多い，業種によって様々ではあるが， 1 年

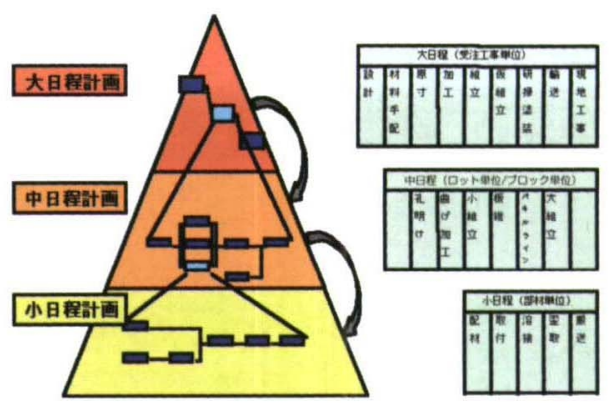

図12 階層型日程計画システムの例

間程度の操業計画を立案する大日程計画， 3 ヶ月程度の 生産計画を立案する中日程計画, そして 1 ケ月程度の工 程実施計画を立案する小日程計画から構成されている。

これらの業種では様々な外乱発生による作業進渉の遅 れを早期に把握し，その対応を取ることが重要であるこ とから, 進渉管理のシステム化にも取り組みがなされて いる.

\section{5. おわりに}

高効率生産に不可欠なマルチロボットを中核とした溶 接のシステム化に関して, $\mathrm{CAD} / \mathrm{CAM}$ 開発事例を中心に 紹介した．物流シミュレーション，生産管理システムに 関しては十分な説明ができていないが，コンピュータ技 術革新により，これらの技術がものづくりの全体最適化， 高効率化に貢献している。 また，システムの最適化技術 は，今後ますます発達していくことを期待する.

\section{参 考 文 献}

1) 長尾ら：舶用ディーゼルエンジンの溶接ロボット用 $\mathrm{CAD} / \mathrm{CAM}$ システムの開発, 本会溶接法研究委員会, SW 2709-00 (2000)

2）芝池：オフラインティーチングシステムを組み合わせた溶 接ロボットシステム，神戸製銅技術がいど， No. 380, vol. 41 (2001), pp6-10

3）勘定ら：MMST銅製セクメント溶接ロボットシステムの 開発, 本会溶接法研究委員会, SW 2877-02 (2002)

4) 勘定ら：造船小組立マルチロボット溶接システムの開発と 実用化, 本会溶接法研究委員会, SW 2398-95 (1995)

5）勘定ら：マルチロボット溶接に执ける溶接経路最適化, 本 会概要, No. 69 (2001), pp376-377

6）藤田ら：受注生産品工場に抒けるバーチャルファクトリー の取り組み，SW 2769-01 (2001) 